\title{
LATTICE INSERTIONS FOR POPAE
}

Y. Cho, E.A. Crosbie, R. Diebold,

D.E. Johnson, S. Ohnuma, A.G. Ruggiero and L.C. Teng

Prepared For

1977 Particle Accelerator Conference

Chicago, I11inois

March 16-18, 1977
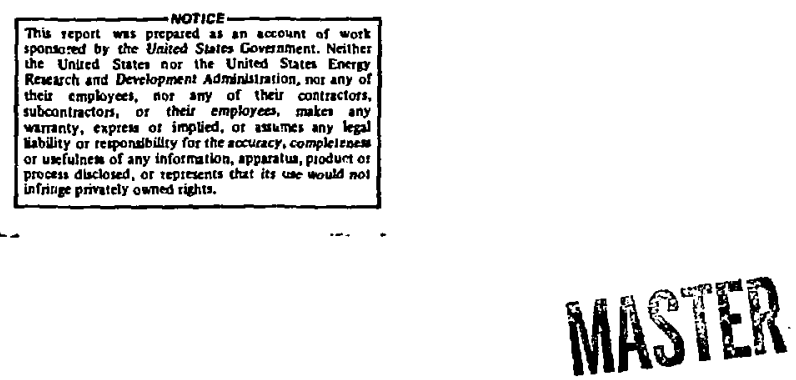

DISTRIBUTION OF THIS DOCUMENT IS UNLIMITED

ARGONNE NATIONAL LABORATORY, ARGONNE, ILLINOIS it

operated under contract $W-31-109-E n g-38$ for the

U. S. ENERGY RESEARCH AND DEVELOPMENT ADMINISTRATION 
The facilities of Argonne National Laboratory are owned by the United States Goversment. Under the terms of a contract (W-31-109-Eng-38) between the U. S. Energy Research and Development Administration, Argonne Universities Association and The University of Chicago, the University employs the staff and operates the Laboratory in accordance with policies and programs formulated, approved and reviewed by the Association.

\section{MEMBERS OF ARGONNE UNIVERSITIES ASSOCIATION}

The University of Arizona Carnegie-Mellon University Case Western Reserve University The University of Chicago University of Cincinnati Illinois Institute of Technology University of Illinois Indiana University Iowa State University The University of Iowa
Kansas State University The University of Kansas Loyola University Marquette University Michigan State University The University of Michigan University of Minnesota University of Missouri Northwestern University University of Notre Dame
The Ohio State University Ohio University

The Pennsylvania State University Purdue University

Saint Louis University Southern Illinois University The University of Texas at Austin Washington University Wayne State University The University of Wisconsin

This report was prepared as an account of work sponsored by the United States Government. Neither the United States nor the United States Energy Research and Development Administration, nor any of their employees, nor any of their contractors, subcontractors, or their employees, makes any warranty, express or implied, or assumes any legal liability or responsibility for the accuracy, completeness or usefulness of any iniormation, apparatus, product or process disclosed, or represents that its use would not infringe privately-owned rights. Mention of commercial products, their manufacturers, or their suppliers in this publication does not imply or connote approval or disapproval of the product by Argonne National Laboratory or the U. S. Energy Research and Development Administration. 


\section{Y. Cho, E.A, Crosble and R. Dichnid}

Argonne Natlonal Laboratorf

9700 South Cass Avenue

Argonne. Illinois 60439

D.E. Johnson, S. Ohnuma, i.G. Ruggtero and L.C. Teng

Fermi Natlonal Accelerator Laboratory*

P.0. Box 500, Batavia, Illinols 60510

\section{Summary}

Four types of insertions are described for the six 200-m stralght sections of POPAE. All have dispersion matched to zero. (1) Injection-efection insertion This has proper high- $B$ values and phase advances for hortzontal injection and vertical ejection. (2) Phaseadjust Insertion - The phase advance in this Insertion is adjustable over a range of $-100^{\circ}$. (3) Generalpurpose Insertion - The $B^{\star}$ is adjustable from 2.5 to $200 \mathrm{~m}$ and the crossing angle $1 \mathrm{~s}$ adjustable from 0 to 11 mrad. (4) High-luminosity Insertion - This gives an even lower $\mathrm{e}^{\star}$ of 1 meter.

\section{General Degcription of the lattice}

The design of POPAE ${ }^{2}$ has evolved into a regular ctructure consisting of $s 1 x, 720-m$ long curved sections, separated by 200-m Iong straight sections where the beass are focused and cross one another. Each sextant Is conposed of 12 lattice cells, having eight 6-m long bending magnets with a fleld of $60 \mathrm{kG}$ at $1000 \mathrm{GeV}$. The two end cells of each sextant are modified to make the dispersion 80 to zero in the straight sections. One bending magnet is omitted from the end cells of the Iniex ring, achleving in a natural way the horlzontal crossing of the beams at 11 mrad.

The regular cell is a separated-function 5000 cell with $90^{\circ}$ betatron phase advance. It consists of two quadrupoles and eight dipoles. Hagnets are separated bJ 80-ca drift to accomodate cryostats and pump-out ports. One palr of beam-positicn seasing electrodes is located in the space iwediately downtream of each quadrupole, and clearing electrodes are placed in all other spaces. Eield-correction windings are located Inside the magnets. The cold-bore vacuum is extended continuously through all regular cells in a curved excetoa.

\section{Disperston Elinination}

The epd cells of each curved section have modified quadrupole strengths such as to set the horizontal dispersion in the adfolning straight section to zero. A single dipole has been removed from the end cells of the outer curved section, being necessary for the croseing geometry and to provide space for the injection kicker. Rewoval of these dipoles provides a horfzontal crossing angle between the beams in the two rings equal to the bending of one dipole, 11 arad. These cells are ahoun in Figs. 1 and 2 . One could have alternatively produced zero dispersion by rearranging dipoles in several end cells, as in the ISABELLE design ${ }^{2}$, but this leads to lower packing factor and so wa not done.

\section{Infection-Efection Insertion}

The lattice Insertion ( $I$ ) In the injection etraight section is shom in FIg. 3 together with the

Moperated by the Universities Research Assocfation. Inc., under contract with the Energy Research and Developaent idolniotration. dispersion-elfoinating cells $\mathrm{Cl}$ and $\mathrm{C2}$ at the upstream and downstream ends, respectively. Also shoun are the stacking rf cavity. the injection septum, the ejection kicker on the upstream side of the crossing point, and the efection septum and Injection kicker on the downstream side.

\section{Phase Adtust Insercion}

The quadrupoles in the phasing straight section insertion $(P)$ are so arranged that by varying their etrengths, the betatron phase advances across the Insercion can be adjusted over a range of some $100^{\circ}$. while keeping the amplitude functions at the ends properly matched, This insertion for two examples vith different phase advance is shom in F1g. 4.

\section{General Purpose Insertion}

A general-purpose insertion that is intended to serve a erest variety of physics experiments should have long central drift space. On the other hand, it should also be able to yleld an amplitude function $B^{*}$ at the crossing point that is small. A low $B^{\star}$ coupled with a long drife space leads to high maximum B-value $\left(B_{\max }\right)$ in the insertion, which is undesirable because it increases the variation of $B$ with nomentum. As a comproalse, a central drift length of \pm 45 m was chosen. At a lou $B(y$ value of $2.5 \mathrm{~m}$ and a hortzontal $B_{\hbar}^{*}$ of $13.5 \mathrm{~m}, B_{\max }$ is about $800 \mathrm{~m}$, and the vartation $B^{*}$ across the morentum spread in the stacked beam is quice colerable and need not be corrected. The tunting range of $\beta^{\text {t }}$ for this Insertion extends fros this Iow value to several hundred meters. Fig. 5 shows the insertion (E) with two sets of running parameters corresponding to the low $\beta_{4}^{*}$ value of $2.5 \mathrm{~m}$ and a high $\beta_{v}^{\star}$ value of $200 \mathrm{~m}$.

\section{High-Luninosity Insertion}

To achieve very high luwinosities the crossing angle can be reduced down to $0^{\circ}$ by the insertion of four bean steering dipoles, EBI to EB4, in the central drift space. In this case, the clear length is reduced to $\pm 10 \mathrm{~m}$. The symmetry in geometry guarantees that, athough the angle dispersion becomes fintte, the displacement dispersion remains zero at the crossing point. The two inner dipoles are used in conwon by the two beams and hence must have a rather wide horizontal aperture of $18 \mathrm{~cm}$. By adfusting $B^{*}$ and the crossing angle, the lumfnosity can be varled over a wide range. As an exauple, high-luninosicy Insertion (H) with a central drift space of $\pm 10 \mathrm{~m}$ is shown in Fig. 6 . This insertion can be tuned to the vertical values of $B^{*}$. 1 and $B_{h}=3 \mathrm{~m}$ and seill has a tolerable $B_{\text {max }}$ of less than $1100=$.

\section{Qperational Considerations}

Oversll lattice characterlsctcs wth a varlety iof Insercions yere studled using the computer progran 'sych.' Those for a typical if are given in Table 1. 
fon a line parallel to and 0.02 sway from the difference dlagonal. This region is free of all regonances below 'sixth order and is large enough to acconmodate tune

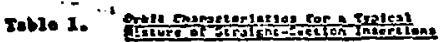

\begin{tabular}{|c|c|c|c|c|c|c|}
\hline 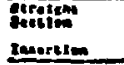 & $\begin{array}{c}2 \\
20 n+(11) \\
\end{array}$ & $\stackrel{2}{\cos ,(x)}$ & $\begin{array}{c}1 \\
(\log .(t) \\
\end{array}$ & $\begin{array}{c}2 \\
\cos (1)\end{array}$ & $\begin{array}{c}E \\
\text { Mnandes }\end{array}$ & $\sum_{n-1 k=(n)}^{2}$ \\
\hline oreatsed gans & II & 21 & 11 & II & 4 & 2 \\
\hline 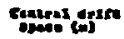 & 230 & as & ass & ots & 130.0 & 100 \\
\hline & so & 3.5 & 258.3 & 211.s & as & 1.8 \\
\hline & 4 & 23.5 & $\mathbf{s}$ & 3 & 91.2 & 1.0 \\
\hline (a) & 213 & mis & 320 & $m$ & 25 & 2018 \\
\hline
\end{tabular}

\section{uratren nowe}

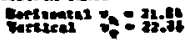

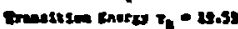

oumetsetiy

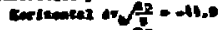

verises acf -43.0

We choose to operate in a region of the tune diagram between the fifth and the integer resonances the chromaticity is tuned to soli postive value suppress the head-tail ef fect. The tune spread in the ctacked beaw needed to suppress all ocher transverse Instablicles by the Landau-damping mechanisa 13 generally small enough so that the operating point on the Injection orbit can also be sccommodated in this region. Thus, only resonances higher than fifth need be crossed during stacking.

1. D. Ayres, et al., "A 1000-GeV on 1000-GeV ProtonProton CoLliding Beam Facllity", Fermllab and Argonne National Laboratory Joint Proposal (Bay 1976)

2. "A Proposal for Construction of a Proton-Proton Storage Accelerator Fac\$11ty ISABELLE", BNL 20161 (June 1976)

3. A.A. Garren and A. Kenny, notes daced Feb. 1974

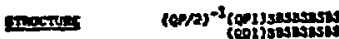

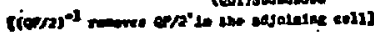

Inopese

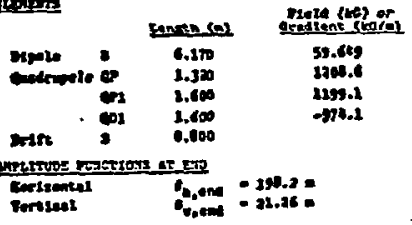

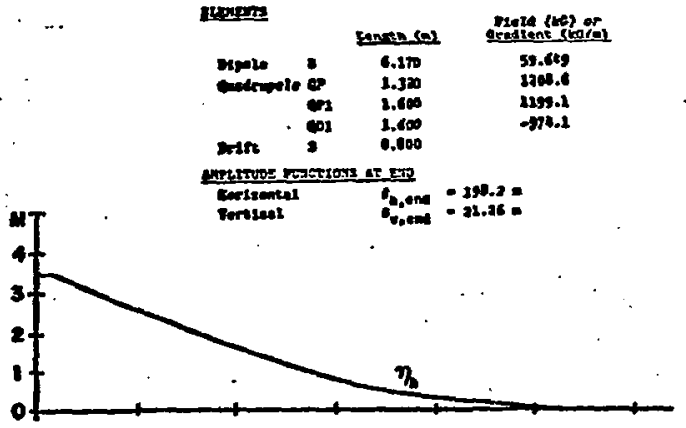

514
15
10
5
0

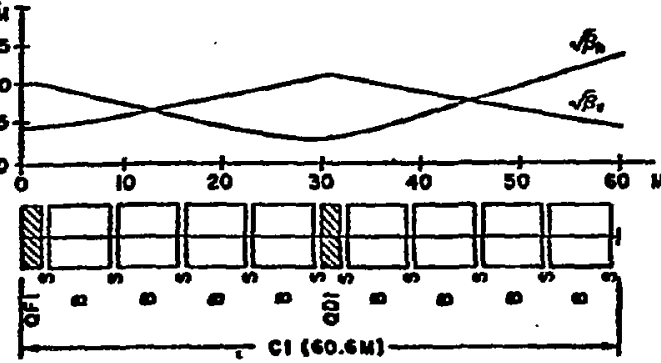

Tle. I Daperalea-efiminuting eell Cl.
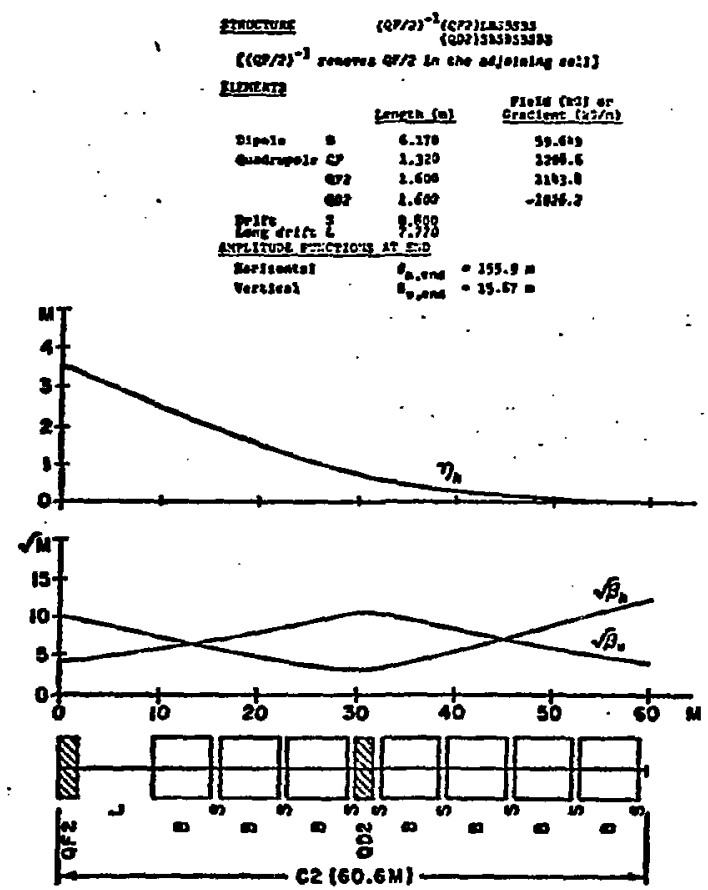

5l. 2 Disperalamelliminating tell C2. 

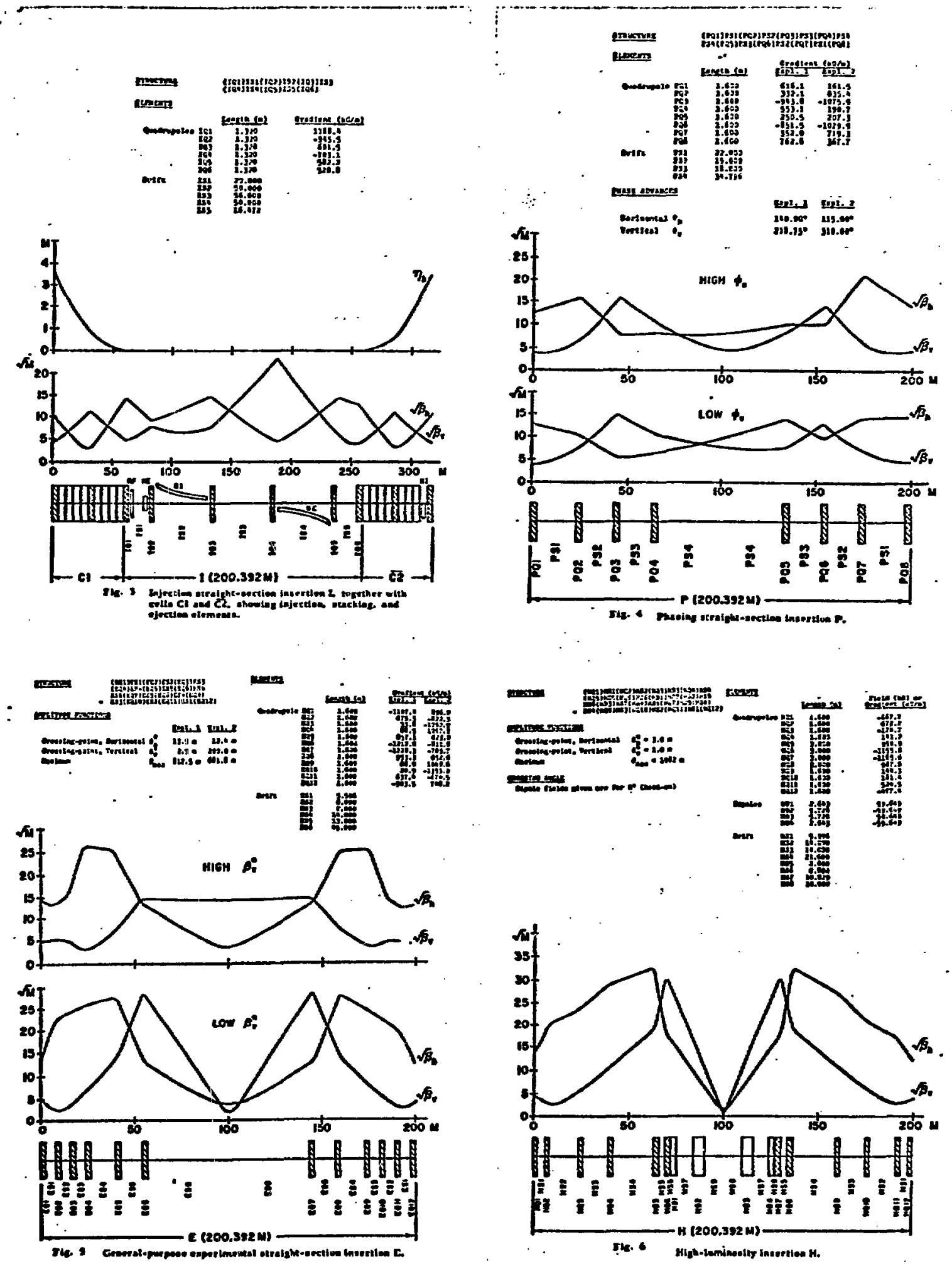

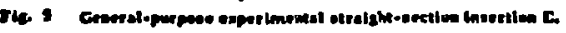

